\title{
2 悪性リンパ腫剖検例の検討
}

\author{
打 越進 - 奥 田稔 \\ （和歌山県立医科大学耳鼻科）
}

最近約 10 年間に和歌山県立医科大学で剖検され た細網肉腫 12 ，リンパ肉腫 2 ,ホジキン病 1 の計 15例の主病変の転移、副病変などについて検討し た。

1）初発部位: 頸部リンパ節 10 , 副鼻腔 1 , 扁桃 1 , 皮膚 1 , 不明 2 例。

2) 初診時 Stage : I $5, \mathrm{I}_{\mathrm{E}} 2, \mathrm{II} 1, \mathrm{I}_{\mathrm{E}} 2$, III 2, III $_{\mathrm{E}^{2}}, \mathrm{II}_{\mathrm{ES}}$ 。

3) 剖検時 Stage : $\mathbb{I I}_{\mathrm{S}} 1, \mathbb{I}_{\mathrm{ES}^{2}}, \mathrm{~N} 12$ 。

4）リンパ節転移：傍気管 $13 、$ 肝膵周囲 $12 、$ 肺内

12、後腹膜 9 、頸、気管分枝、鼠径 8 、腸間膜、 腋下 7 、胃周囲 5 。

5) 蔵器転移：脾 $12 、$ 肺 $10 、$ 骨䯣 9 、肝 9 、腎 8 、 副腎、膵 7、肋膜、胃 4、気管、気管支、膀胱、 前立腺 3、横隔膜、心など 2、舌根、喉頭など 1 。

6）副病変（主な致死因子として）：胸部疾患 9

( Pulmonary fibrosis 2 , B ronchopneumonia 3 , Pulmonary edema 4 )、出血 2 (腸 間、頭蓋内)。䯣膜炎 1 、Cachexia 2 、尿管 閉塞 1 。

リンパ節転移は上皮性腫痬（河辺 1966 年によ る）では局所リンパ節が遠隔リンパ節の 2 倍転移 が多いのに比して、悪性リンパ腫では同程度であ ク、またその頻度も高かった。頭頸部原発の12例
中全例が遠隔リンパ節への転移を認め、表在リン パ節よりも深部リンパ節に高頻度にみとめられた。

蔵器転移は上皮性腫瘍に比し、肺においては 2 倍以上、肝では約 3 倍、脾では圧倒的に多数であ るのは当然としても、脺、腎でも著明に多く認め られた。肺転移の 10 例中レントゲン上結節をみと められたのは 1 例 脾腫が認められたのは 2 例に すぎなかった。肝腫大が比較的腫痬浸潤と一致し ていた。

質問松村（九州がんセンタ一）

多中心性発生と確定された例はどのような所見 を呈していたか御教え願いたい。

回答

打越 (和医六)

剖検時所見上り、多中心性発症か否かは明らか にできなかった。

質問 大山 ( 鹿大耳鼻科)

出血死とあるのは消化管出血によるものか。

もしそうであれば、腫瘍によるものか。潰瘍の 悪化によるものか、その他原因によるものか等に ついてその所見ないしは扮考えを御教示下さい。 回答 打越 (和医大)

消化管出血で致死的な因子となった症例では、 出血、潰瘍部分腫瘍細胞の浸潤を認めた、その他 の小出血部、潰痬部では、畽痬の存在する場合と しない場合があった。 